\title{
max \\ Householders Attitude, Preferences, and Willingness to Have Home Garden at Time of Pandemics
}

\author{
Aydin Basarir, Noura M. N. Al Mansouri and Zienab F. R. Ahmed *(D)
}

Citation: Basarir, A.;

Al Mansouri, N.M.N.; Ahmed, Z.F.R. Householders Attitude, Preferences, and Willingness to Have Home Garden at Time of Pandemics. Horticulturae 2022, 8, 56. https:// doi.org/10.3390/horticulturae8010056 Academic Editors: Andrea Ertani and Roberta Bulgari

Received: 25 December 2021

Accepted: 1 January 2022

Published: 8 January 2022

Publisher's Note: MDPI stays neutral with regard to jurisdictional claims in published maps and institutional affiliations.

Copyright: (C) 2022 by the authors. Licensee MDPI, Basel, Switzerland. This article is an open access article distributed under the terms and conditions of the Creative Commons Attribution (CC BY) license (https:// creativecommons.org/licenses/by/ $4.0 /)$.
Integrative Agriculture Department, College of Agriculture and Veterinary Medicine, United Arab Emirates University, Al Ain 15551, United Arab Emirates; abasarir@uaeu.ac.ae (A.B.); 201103928@uaeu.ac.ae (N.M.N.A.M.)

* Correspondence: zienab.ahmed@uaeu.ac.ae; Tel.: +971-5052-08360

\begin{abstract}
The value of home gardens has become more apparent among tenants forced into isolation in difficult and uncertain times arising since the COVID-19 pandemic started the beginning of 2020. While gardens make a significant contribution to the social and ecological environment of cities, most studies have focused on public green spaces. Investigating householder preferences for gardens during and after the mandatory lockdown period in the UAE is required. The main objective of this study is to analyze the householder's attitude, preferences, and willingness to have home gardens during the pandemic and after. The data were collected via an online survey of randomly selected respondents. A logistic econometrical model was utilized to analyze the factors affecting respondent preferences regarding having a garden. According to the results, the probability of having a garden increases among respondents who produce some crops, have attained Msc/PhD. level, a backyard, and a larger space to cultivate. It decreases among those who are married, find it hard to take care of a garden, and face a weed problem. In conclusions, it is highly recommended for householders to have home gardens, which can provide a quality lifestyle and enhance leisure time during the pandemic and after.
\end{abstract}

Keywords: pandemic; home garden; lifestyle; householders; vegetables

\section{Introduction}

A garden is a plot of ground where herbs, fruits, flowers, vegetables, or ornamental plants are cultivated [1]. While ornamental plants are planted for decorative purposes, the others are grown for both aesthetics and family consumption. Gardening is considered a great way to enjoy the outdoors. Tenants mainly use it as a leisure time, relaxing activity on weekends and vacation.

Local gardens are an important component of the green landscape, yet their specific contribution to well-being is rarely assessed relative to urban green space [2]. A recent editorial highlighted the growing need to become better informed about ways to understand and promote health and well-being during this time [3]. Two recent population surveys in the UK indicated that having access to, and spending time in private gardens, is positively associated with enhanced well-being [4,5]. Having a home garden and spending time cultivating fruits, vegetables, and ornament plants will increase their productivity and satisfaction. Tenants can enjoy leisure time while producing fresh, healthy, organic, and pesticide- and chemical-free products in their gardens.

Switching to vegetable gardening during leisure time relieves a level of stress and provides a healthy lifestyle. The satisfaction mainly comes from dealing with producing fruits and vegetables in a home garden and harvesting them when they are ripe and flavorful. Thus, investigating the householder's awareness and willingness to have home gardens, especially during the quarantine period, is worth investigating.

Even though gardens are preferred by tenants in general, there are some challenges they may face. Insufficient space, lack of time, the high cost of materials, and limited 
experience are well-known challenges. In addition, climatic conditions also influence cultivating some products. The selection of plant species to be cultivated in outside home spaces should be based primarily on their ability to cope with the harsh conditions of the urban environment, such as high wind, irradiance, lack of organic material and nutrients, and intermittent drought [6]. Therefore, careful plant selection should be integrated into outside space design [3,7-9].

No matter how small the home gardens are, one can start with pots then increase gradually, and eventually, gained experience, the garden can be a huge plot of plants [10]. The trees and plants cultivated in gardens clean the air from excess carbon dioxide, provide oxygen, and act as the breathing lungs of cities. A healthy and enjoyable environment can be obtained by increasing the area of gardens, which includes aesthetic and creative elements. Garden benefits are also linked to the restorative properties of nature. A garden can help children explore nature, help them discover the world and develop their skills and knowledge accordingly [11]. In addition to aesthetic views, the gardens can provide fresh fruits and vegetables for family consumption. The pandemic situation familiarizes the tenants with some level of technology used in agriculture and helps them enjoy outdoor life [12-14].

The coronavirus (COVID-19) outbreak began in Wuhan and has since spread across China and the rest of the world, shutting down entire cities, threatening the health of thousands, and instantaneously testing the strength of the global economy. Schools, universities, libraries, museums, and theatres were shut down. Because of the extreme contagiousness of COVID-19, unnecessary activity outside has been strongly discouraged. Within a few days, daily life was turned upside down and people were forced to change their lifestyle, self-quarantine, work from home, go to online schools, and change shopping habits.

Despite the fact they are having a difficult time these days, some people decided to reduce their stress and psychological load by having a garden. A garden makes them partially self-sufficient by growing needed fresh vegetables, even if they don't live in the country or have open spaces to grow them [3,15-17]. Moreover, spending time in such environments can provide several advantages such as social interaction with guests/relatives, physical exercise, better health, and improved sleep quality [18-21]. In addition to that, enjoying the beauty of ornamental plants and consuming fresh products produced in the gardens increase householder satisfaction. Access to outdoor and urban green space is extremely important to the recovery program of COVID-19 [22,23].

Statistics indicated attendance at a high number of parks and gardens all around the world during the pandemic. Most countries have re-opened garden centers by $96 \%$ capacity, and lots of young people have started to work with plants and gardens during the crisis. As demand for gardening increased, garden items have been among the most popular online ordered products [5]. Thus, the tenants have allocated more time to cultivate and decorate the gardens.

There has been much research in literature indicating the beneficial effects of gardens on tenants and activities performed in them. Cervinka et al. [24] investigated the perceived restorative properties of private gardens and their predictors via a survey conducted on 856 respondents. According to results, the private garden scored highest in perceived restorativeness, and the garden-user-relationship qualified as the strongest predictor of restorative potential.

Chalmin-pui et al. [25] searched attitudes and the perceived health benefits of home gardening via a survey conducted with 5766 gardeners and 249 non-gardeners. They investigated the answer to the question "why residents engaged in gardening and the extent to which they recognized health benefits from the activity"? They found a significant association between improvements in well-being, perceived stress, physical activity through more frequent gardening.

Leisure preferences have been researched using different variables. Gender, age, race, personality, and other attributes are the main variables. That is why there should be a correlation between the different but related leisure activities preferred by people [26]. 
Cheng et al. [27] applied the concept of serious leisure to the context of leisure gardening by older adults in Australia by conducting a survey with 514 respondents. According to their results, characteristics of serious leisure varied significantly across identity, unique ethos, and effort required. The higher the level of engagement, the more gardening was perceived as contributing to overall life satisfaction. Their findings indicated that "gardening could be a serious leisure pursuit that assists in developing a positive leisure identity and contributes to a more mobile and active life for older adults".

Dunnett and Qasim [12] investigated the role of private urban gardens in human well-being with randomly selected garden owners from the city of Sheffield, England. They discussed the perceived value that gardens have to the well-being of people, both individually through the enjoyment of their own gardens and collectively through the contribution of city gardens to environmental enhancement. They indicated a relationship between these values and some indicators such as age, gender, social demographics, etc.

Food production in home gardens can have symbolic and practical importance in sustainable cities. One can better understand vegetable gardening in public spaces and community gardens rather than engaging in the same activity on private property. Krikpatrick and Davison [28] studied home-grown garden practices and motivations in urban domestic vegetable production by questioning 101 gardeners in Hobart, Tasmania, Australia. According to their results, while all respondents were motivated to grow vegetables for pleasure, many were also activists wishing to promote social change, while others wished to ensure affordable access to vegetables or to improve health. With the exceptions of the activists and food fashionistas, garden type, gardening practice, and gardener motivation were not strongly interlinked. Family members were identified as important sources of information and inspiration. Those without family role models were either influenced by new food cultures or were low income and wanted affordable access to vegetables.

Although some gardening benefits have been documented in literature, the motivations regarding participation in gardening activities are often considered based on anecdote [29]. McFarland et al. [29] used qualitative analysis to explore reasons gardeners from different genders and generations participate in gardening through 177 conducted surveys. They found statistically significant differences in comparisons among males and females with more males gardening for food/health/nutrition and nostalgic reasons. More females reported gardening for personal productivity when compared with males. No significant difference was identified in comparisons of gardeners from various age groups indicating that gardeners across generations have similar intentions and receive similar benefits

With people now facing uncertain and difficult times in the face of COVID-19, it has been thought that information is lacking regarding the importance of home gardens, especially during the pandemic. To the best of our knowledge, to date, there have been no studies investigating householder awareness and willingness to have home gardens during the mandatory lockdown period in the UAE. Therefore, the main objective of this study is to analyze the householder's attitudes, preferences, and willingness to have home gardens during pandemics. The specific objectives are to: (I) determine the current structure of home gardens and their cultivation; (II) Identify the respondent's opinion regarding the importance of home garden during the pandemics; (III) get some demographic information; and (IV) analyze the factors affecting the householder's preferences of having the gardens. The results of the analysis and some recommendations will be shared with the decisionmakers in encouraging the householders to have home gardens.

Al Ain city was selected as a study area. The city is commonly referred to as the "garden city" of UAE due to its green areas, oases, and parks [30,31]. The majority of the residences in the city possess a home with a garden. Having landscaped space that not only looks wonderful but also improves the surrounding environment. Even though the residents enjoy the fruits and vegetables produced on it, the gardens are mainly established for aesthetic purposes. 


\section{Materials and Methods}

The data required for the analysis was collected via survey and secondary data sources. A questionnaire was developed to collect data for the current structure of home gardens in Al Ain. The survey included questions related to the determination of home garden and cultivation, the respondent's opinion regarding the importance of home garden during the pandemics, and some demographic questions related to age, gender, and accommodation.

Al Ain city population is 766,936 . According to statistical analysis, the samplerequired was 384 respondents. In order to increase the representative power of the sample 663 respondents were selected and surveyed. The questionnaire was pilot tested firstly to make sure the questions would be understood by householders when conducted.

The survey was conducted during a crisis, and it was difficult to conduct face-to-face surveys during lockdown time when the residents were asked to stay at home for a certain period. Therefore, the survey had to be conducted online. The survey targeted randomly selected Al Ain city residents with different backgrounds.

The survey was distributed through emails, WhatsApp, and social media presenters to all UAE University (UAEU) members, staff, students, teachers, families, friends, and different groups. A poster with the questionnaire logo and link barcode had been created. A total of 15 posters and 100 A4 paper printed posters were prepared. The posters were distributed around the most important agricultural areas in the city of Al Ain: supermarkets, cafes, restaurants, and places that sell fresh vegetables. In addition, posters were displayed at the main building of UAEU, hung on walls, in elevators, at grocery outlets, in corridors, on doors, and important entrances on campus.

A set of various seeds for flowers and vegetables was given to the respondents as an encouragement gift to take the survey and start with the first step of planting in their garden. The gifts were placed in a basket next to some posters but not all, due to some restrictions implemented by the UAE government to prevent the spread of COVID-19. The poster was decorated by placing a grass carpet in front strewn with vegetables and representative fruits to draw the attention of the passersby to stop and participate in the survey.

Since it was difficult to have a face-to-face survey with randomly selected respondents in Al Ain, the steps mentioned above were followed. The authors were aware of the sampling bias in such a survey conducting the procedure. In order to decrease the bias, the number of respondents was increased with different incentive activities mentioned above.

Based on the conducted survey, the questions were coded and entered to an excel sheet. The process included binomial (yes/no), continuous (Age), ordered (income level), and likert scale questions. In addition to deterministic statistics and frequency tables, data were econometrically analyzed by utilizing logistic regression models to test the kind of factors affecting the probability of householders willing to have home gardens. An SPSS econometrical program was used for the analysis of data.

The Logistic Model assumes the probability of and outcome occurrence, $P_{i}$, is dependent on a number of independent variables $\left(X_{i j}\right)$ associated with respondents $i$ and variable $j$, and a number of unknown parameters $\beta[32,33]$.

The model was stated as:

$$
P_{i}=\operatorname{Pr}\left(y_{i}=1 \mid x_{i}\right)=\frac{\exp \left(x_{i} \beta\right)}{1+\exp \left(x_{i} \beta\right)}=\frac{1}{1+\exp \left(-x_{i} \beta\right)}
$$

where the right-hand side of Equation (1) is the cumulative distribution function (cdf) of probabilities of having home garden and the variance for the logistic distribution is:

$$
\sigma^{2}=\pi^{2} / 3
$$

$P_{i}=$ is the probability that a householder has a home garden; $i=1,2, \ldots, \mathrm{n}$ are the number of respondents; $x_{i}=$ the $n$th explanatory variable for the $i$ th respondent of having a home garden; $\beta=$ the parameters to be estimated; and $\varepsilon$ is the error term. 
The likelihood of observing the respondent's probability of having a home garden was hypothesized to be a function of a set of independent variables, as will be illustrated in the results section. The majority of variables used in the analysis, such as demographics, were adopted from the literature, and remaining issues, such as obstacles, were included based on the observations of researchers and related publications.

OOWNHG $=\mathrm{f}(\mathrm{CROPP}, \mathrm{OBSTAC}$, DIFFIC, IRRSYS, WEEDS, TCARE, GENDER, AGE, EDUC, MARITAL, KIDS, ACCDTYP , BYARD, SPCAPA, JOB, INCOME)

where: OWNHG: If the respondent has a home garden; CROPP: If there is food crop production from the Garden; OBSTAC: Obstacles to have a Garden; DIFFIC: Difficulties to take care of Garden; IRRSYS: Irrigation System; WEEDS: If there is harmful weeds; TCARE: If the respondent is the one who takes care of garden; GENDER: Gender; AGE: Age; EDUC: Education level; MARITAL: Marital Status; KIDS: If has kids; ACCDTYP: Accommodation Type; BYARD: If the respondent has a backyard; SPCAPA: Space Capacity; JOB: If the respondent has a job; INCOME: Average Monthly Income.

It seems logical that the respondent who faces obstacles, weed problems, finds it hard to take care of a garden, and has a job is not willing to have a home garden. That is why H1 has developed as follows.

Hypothesis 1 (H1). OBSTAC, DIFFIC, WEEDS, and JOB are negatively related to the probability of having a home garden.

The remaining variables are expected to have positive effects on willingness to have a home garden. That is why the following hypothesis was developed.

Hypothesis 2 (H2). CROPP, IRRSYS, TCARE, GENDER, AGE, EDUC, MARITAL, KIDS, ACCDTYP, BYARD, SPCPA, and INCOME are positively related to the probability of having $a$ home garden.

\section{Results}

The selected variables used in the econometric analysis are given in Table 1 . The results in the table show that 89 percent of householders in Al Ain seem to have a home garden and produce some food crops. The factors affecting the respondents to have a home garden are given in the table and will be used in the econometric analysis in the logistic regression part.

Table 1. Deterministic Statistic of the Variables Used in the Analysis.

\begin{tabular}{|c|c|c|c|c|c|}
\hline Variables & Number & Min & Max & Mean & SD \\
\hline $\begin{array}{l}\text { OWNHG: If respondent has a home garden } \\
\text { (Yes: } 1 \text { and No: } 0 \text { ) }\end{array}$ & 662 & 0 & 1 & 0.89 & 0.308 \\
\hline $\begin{array}{l}\text { CROPP: If there is Food crop production from the Garden } \\
\text { (Yes: } 1 \text { and No: } 0 \text { ) }\end{array}$ & 661 & 0 & 1 & 0.81 & 0.394 \\
\hline $\begin{array}{l}\text { OBSTAC: Obstacles to have a Garden } \\
\text { (Need Experience and Knowledge: } 1 \text { others: } 0 \text { ) }\end{array}$ & 663 & 0 & 1 & 0.64 & 0.481 \\
\hline $\begin{array}{l}\text { DIFFIC: Difficulties to take care of Garden } \\
\text { (Yes: } 1 \text { and No: } 0 \text { ) }\end{array}$ & 663 & 0 & 1 & 0.57 & 0.496 \\
\hline $\begin{array}{l}\text { IRRSYS: Irrigation System } \\
\text { (Manual: } 1 \text { Automatic: 0) }\end{array}$ & 663 & 0 & 1 & 0.60 & 0.489 \\
\hline $\begin{array}{l}\text { WEEDS: If there is harmful weeds } \\
\text { (Yes: } 1 \text { and No: } 0 \text { ) }\end{array}$ & 661 & 0 & 1 & 0.37 & 0.483 \\
\hline
\end{tabular}


Table 1. Cont.

\begin{tabular}{|c|c|c|c|c|c|}
\hline Variables & Number & Min & Max & Mean & SD \\
\hline $\begin{array}{l}\text { TCARE: If respondent is the one who takes care of garden } \\
\text { (Yes: } 1 \text { and Others: } 0 \text { ) }\end{array}$ & 649 & 0 & 1 & 0.36 & 0.481 \\
\hline GENDER: Gender (Male: 1 and Female: 0) & 643 & 0 & 1 & 0.79 & 0.405 \\
\hline $\begin{array}{l}\text { AGE: Age } \\
\text { (Less then 18: 1, 19-40: 2, 41-60: 3, Older than 60: 4) }\end{array}$ & 652 & 1 & 4 & 2.13 & 0.481 \\
\hline $\begin{array}{l}\text { Educational level } \\
\text { EDUC1High School and less: 1, } \\
\text { EDUC2: BSc: 2, } \\
\text { EDUC 3: MSc/PhD: } 3\end{array}$ & $\begin{array}{c}45 \\
495 \\
103\end{array}$ & $\begin{array}{l}0 \\
0 \\
0\end{array}$ & $\begin{array}{l}1 \\
1 \\
1\end{array}$ & $\begin{array}{l}0.07 \\
0.77 \\
0.16\end{array}$ & $\begin{array}{l}0.255 \\
0.421 \\
0.367\end{array}$ \\
\hline $\begin{array}{l}\text { MARITAL: Marital Status } \\
\text { (Married: } 1 \text { and others: } 0 \text { ) }\end{array}$ & 653 & 0 & 1 & 0.42 & 0.494 \\
\hline $\begin{array}{l}\text { KIDS: If has kids: } \\
\text { (Yes: } 1 \text { and No: } 0 \text { ) }\end{array}$ & 651 & 0 & 1 & 0.39 & 0.488 \\
\hline $\begin{array}{l}\text { ACCDTYP: Accommodation Type } \\
\text { (Own property: } 1 \text { and Rent } 0 \text { ) }\end{array}$ & 651 & 0 & 1 & 0.81 & 0.389 \\
\hline $\begin{array}{l}\text { BYARD: If has a backyard } \\
\text { (Yes: } 1 \text { and No: } 0 \text { ) }\end{array}$ & 649 & 0 & 1 & 0.90 & 0.294 \\
\hline $\begin{array}{l}\text { SPCAPA: Space Capacity: } \\
\text { (Big: } 1 \text { and Small: } 0 \text { ) }\end{array}$ & 650 & 0 & 1 & 0.62 & 0.487 \\
\hline $\begin{array}{l}\text { JOB: Do you work? } \\
\text { (Yes: } 1 \text { and No: } 0)\end{array}$ & 647 & 0 & 1 & 0.40 & 0.490 \\
\hline $\begin{array}{l}\text { INCOME: Average Monthly Income: } \\
\text { (Less than AED 10,000: 1, 10,000-30,000: 2, and more than 30,000: } 3 \text { ) }\end{array}$ & 580 & 1 & 3 & 1.94 & 0.790 \\
\hline
\end{tabular}

Table 2 shows the kind of crops produced in respondents' gardens. As can be seen from the table, the majority of them have a productive home garden with both fruits and vegetables. The majority of respondents seem to be producing date palm (84.6\%), followed by seder (69.5\%), cactus (63.5\%), Lemon (58.4\%), and Mango (51.9\%). Among the fruits, arta and bananas seem to be the least favored product by the householders.

Table 2. The Kind of Crops Produced in the Home Gardens in Al Ain.

\begin{tabular}{cccc}
\hline \multicolumn{2}{c}{ Fruits and Native Plants } & \multicolumn{2}{c}{ Vegetables and Flowers } \\
\hline Products & \% of Respondents & Products & \% of Respondents \\
\hline Figs & 41.2 & Cucumber & 23.6 \\
\hline Mango & 51.9 & Tomato & 54.4 \\
\hline Orange & 18.1 & Onion & 33.2 \\
\hline Lemon & 58.4 & Potato & 17.6 \\
\hline Pomegranate & 43.4 & Carrot & 82.4 \\
\hline Berries & 32.9 & mushroom & 3.0 \\
\hline Bananas & 13 & Lettuce & 27.9 \\
\hline Date Palm & 84.6 & Coriander & 38.9 \\
\hline Gahf & 23.4 & Parsley & 41 \\
\hline Seder & 69.5 & Mint & 41 \\
\hline Henna & 23.2 & Rocca & 44.9 \\
\hline Arta & 7.2 & Rose & 45.9 \\
\hline
\end{tabular}


Table 2. Cont.

\begin{tabular}{cccc}
\hline \multicolumn{2}{c}{ Fruits and Native Plants } & \multicolumn{2}{c}{ Vegetables and Flowers } \\
\hline Products & \% of Respondents & Products & \% of Respondents \\
\hline Cactus & 63.5 & Jasmine & 68.5 \\
\hline & Lavender & 61.6 \\
\hline & Sunflower & 18.6 \\
\hline
\end{tabular}

In addition to fruits, the gardens are suitable for cultivating vegetables for consumption and flowers for aesthetic reasons. A significant number of respondents seems to like the production of carrots $(82.4 \%)$, tomatoes $(54.4 \%)$, rocca $(44.9 \%)$, followed by parsley $(41 \%)$ and mint (41\%).

A beautiful and important element of the garden is the presence of flowers and roses. Among the flowers, jasmine (68.5\%), lavender (61.6\%), and bougainvillea (52.3) seem to be the most cultivated, compared to other kinds. While mushrooms seem to be the least produced (3\%) vegetable, sunflowers are the least produced (18.6) flower.

As indicated in Table 3, some sentences were given to determine the respondents' opinion regarding the importance of home gardening during the pandemics. As can be seen from the table, almost all respondents agreed on the judgment indicated in the sentences. They seem positive about the benefits a home garden provides. The most favored sentence was "The home garden is important especially in times of pandemics and disasters" (78.4\%) followed by sentences: "Having a home garden is important for children to enjoy nature during the lockdown" (77.3\%) and "The home garden can contribute to a good mood and reduce depression for people during the time of lockdown" $(75.4 \%)$.

Table 3. The Respondent's Opinion regarding the Importance of a Home Garden During Pandemics (SA: Strongly Agree, A: Agree, N: Neutral, D: Disagree, SD: Strongly Disagree).

\begin{tabular}{lccccc}
\hline \multicolumn{1}{c}{ Sentences } & SA & A & N & D & SD \\
\hline $\begin{array}{l}\text { A productive home garden is essential } \\
\text { for everyone. }\end{array}$ & 62.9 & 27.9 & 8.0 & 1.1 & 0.2 \\
\hline $\begin{array}{l}\text { The home garden supplies healthy organic food to } \\
\text { family members. }\end{array}$ & 64.5 & 27.8 & 6.8 & 0.8 & 0.2 \\
\hline $\begin{array}{l}\text { The home garden is important, especially in times } \\
\text { of pandemics and disasters. }\end{array}$ & 78.4 & 19.0 & 2.4 & 0.2 & 0.2 \\
\hline $\begin{array}{l}\text { The home garden can be an alternative to the } \\
\text { market, in getting fresh products? }\end{array}$ & 54.9 & 26.8 & 13.0 & 4.2 & 1.1 \\
\hline $\begin{array}{l}\text { The garden products are sufficient if they cannot } \\
\text { be found in the market during the days of } \\
\text { the lockdown. }\end{array}$ & 34.3 & 28.8 & 21.8 & 11.9 & 3.1 \\
\hline $\begin{array}{l}\text { The home garden can contribute to local food } \\
\text { security if necessary. }\end{array}$ & 47.0 & 36.1 & 13.3 & 2.7 & 0.9 \\
\hline $\begin{array}{l}\text { The home garden can contribute to a good mood } \\
\text { and reduce depression for people during the time } \\
\text { of lockdown. }\end{array}$ & 75.4 & 21.0 & 3.3 & 0.2 & 0.2 \\
$\begin{array}{l}\text { The homes garden is a place to spend time with } \\
\text { family members and participate in the housework. }\end{array}$ & 74.5 & 21.4 & 3.5 & 0.5 & 0.2 \\
\hline $\begin{array}{l}\text { Having a home garden is important for children to } \\
\text { enjoy nature during the lockdown. }\end{array}$ & 77.3 & 19.8 & 2.2 & 0.5 & 0.2 \\
\hline
\end{tabular}


Table 3. Cont.

\begin{tabular}{lccccc}
\hline \multicolumn{1}{c}{ Sentences } & SA & A & N & D & SD \\
\hline $\begin{array}{l}\text { Home gardening teaches children the importance } \\
\text { of healthy food and makes them consume its } \\
\text { products in their meals. }\end{array}$ & 65.7 & 25.4 & 7.5 & 1.1 & 0.3 \\
\hline $\begin{array}{l}\text { We should seriously think about starting to have } \\
\text { productive home gardens. }\end{array}$ & 60.1 & 30.1 & 7.5 & 1.6 & 0.6 \\
\hline $\begin{array}{l}\text { Everyone wishes to have a home garden that } \\
\text { provides healthy food. }\end{array}$ & 71.9 & 22.6 & 4.7 & 0.2 & 0.6 \\
\hline $\begin{array}{l}\text { We should support attending workshops to learn } \\
\text { how to take care of plants. }\end{array}$ & 58.2 & 30.4 & 9.4 & 1.4 & 0.6 \\
\hline $\begin{array}{l}\text { Home gardening can supply healthy, organic food } \\
\text { to family members. }\end{array}$ & 64.5 & 27.8 & 6.8 & 0.8 & 0.2 \\
\hline
\end{tabular}

A logistic regression analysis was utilized to reveal factors affecting the probability of having a home garden (Table 4). According to the results, even though the effects of all variables on the probability of having a home garden seem logical, only seven of them had significant effects. Four independent variables were expected to negatively affect the probability of having a home garden. Of the four variables, the difficulties of taking care of a garden (DIFFIC), and facing harmful weeds (WEEDS) were significant as expected. The respondents faced with the difficulties of taking care of a garden and must deal with the harmful weed problem will unlikely support the idea of having a home garden. Thus, H1 can be considered as approved.

Table 4. The Analysis of the Factors Affecting Householders Willingness to Have Home Garden in Al Ain.

\begin{tabular}{lccccc}
\hline Variables & B & S.E. & Wald & Sig. & Exp(B) \\
\hline Constant & -4.146 & 1.521 & 7.425 & 0.006 & 0.016 \\
\hline CROPP & 0.853 & 0.411 & 4.316 & 0.038 & 2.347 \\
\hline OBSTAC & 0.511 & 0.388 & 1.738 & 0.187 & 1.667 \\
\hline DIFFIC & -0.775 & 0.402 & 3.724 & 0.054 & 0.461 \\
\hline IRRSYS & 0.547 & 0.425 & 1.653 & 0.199 & 1.728 \\
\hline WEEDS & -0.766 & 0.375 & 4.186 & 0.041 & 0.465 \\
\hline TCARE & 0.415 & 0.426 & 0.950 & 0.330 & 1.514 \\
\hline GENDER & 0.195 & 0.477 & 0.167 & 0.683 & 1.215 \\
\hline AGE & 0.778 & 0.484 & 2.583 & 0.108 & 2.177 \\
\hline EDUC2 & 0.751 & 0.598 & 1.580 & 0.209 & 2.120 \\
\hline EDUC3 & 1.319 & 0.788 & 2.803 & 0.094 & 3.740 \\
\hline MARITAL & -1.488 & 0.694 & 4.593 & 0.032 & 0.226 \\
\hline KIDS & 0.907 & 0.676 & 1.798 & 0.180 & 2.476 \\
\hline ACCDTYP & 0.635 & 0.493 & 1.656 & 0.198 & 1.887 \\
\hline BYARD & 2.749 & 0.437 & 39.510 & $<0.001$ & 15.632 \\
\hline SPCAPA & 1.462 & 0.438 & 11.130 & $<0.001$ & 4.316 \\
\hline JOB & -0.408 & 0.462 & 0.780 & 0.377 & 0.665 \\
\hline INCOME & 0.221 & 0.265 & 0.695 & 0.405 & 1.247 \\
\hline & & & & & \\
\hline
\end{tabular}


There were 12 independent variables hypothesized to be positively related to the probability of having a home garden. Of the twelve variables, If there is food crop production from the garden (CROPP), the education level (EDUC3) of respondents, having back yard (BYARD) or a larger space (SPCAPA) for the gardens are statistically significant. Producing some crops, being well educated, and having a large space/back yard are known to be among the most important factors regarding having a home garden. That is why, the effects of CROPP, EDUC3, BYARD, and SPCAPA were expected. The variable whose negative effect was not expected is if the respondent were married (MARITAL). The possible reason might be because married respondents with a larger family are expected to have a job and might not have enough time to spend on a home garden. The effects of the remaining variables were as expected but insignificant. Thus, $\mathrm{H} 2$ can be considered as approved.

\section{Discussion}

The impression of a home garden in $\mathrm{Al}$ Ain and its importance during the pandemic has been discussed. The finding supports the judgment that the householders are aware of the value of having a home garden during pandemics. Most of the householders in $\mathrm{Al}$ Ain think home gardens are helpful to maintain human well-being, contribute to modifying the mood, and reduce depression. These findings seem similar to the results of some researches conducted by Dunnett and Qasim [12], Cervinka, et al. [24], Chalmin-pui, et al. [25], Fox [26], Cheng, et al. [27], krikpatrick and Davison [28], McFarland, et al. [29], etc. In addition, a garden is a healthy place for a family gathering. As indicated in previous work conducted by Chenaride et al. [34] and Walljasper and Polansek [35], gardening was also adopted as an activity for children, as well as, filling free time due to loss of work, canceled events, and closed businesses.

A Garden is a place that suits all family members; the elderly, children, and adults. It is where the journey of adventure and happy memories begin, as nature greatly reduces stress and improves mood. The results support the idea that home gardens enhance the householder's quality of life.

As a part of the urban green infrastructure, the edible landscape plays an important role in improving the environment, maintaining self-supporting systems, and enriching greenspace functions. Gardens improve our environment and reduce air pollution. Rapid urbanization leads to the increase of urban population and the replacement of agricultural lands by construction lands.

The 'nature' of garden activity (i.e., whether for gardening or relaxing) may not be as important to well-being during the pandemic as the amount of time spent in the garden. To our knowledge, we provide the first empirical evidence of a link between owning a home garden to greater well-being during the COVID-19 pandemic. In these unprecedented times of uncertainty and stress, domestic gardens may provide an outlet for mental activity, as well as boosting physical health, especially for older people under extended home quarantine $[4,36]$.

\section{Conclusions}

It is clear that home gardens are valuable for the residents who utilize them. A garden has cultural, emotional, psychological, and even spiritual value for tenants. In this study, a questionnaire survey was conducted to collect information about the Al Ain city's householders' attitudes, preferences, and willingness to have a home garden during the pandemic and after. The results suggest that the householders benefit from the gardens through contact with plants and nature, enjoying the products they produce, and the aesthetic view of flowers. Thus, one can conclude that the respondents are aware of the home garden's benefits, have a positive attitude toward them, and prefer/want to have them as a place for leisure time and well-being. The gardens play an important role in the life of householders by providing clean air to breathe and a positive influence on their well-being. Since the gardens are considered the lungs of cities, the decision-makers can 
encourage and help residents establish home gardens with plants, flowers, and different kinds of crops.

Study findings suggest that the value of a home garden needs further research in the context of leisure, cultivation, and aesthetics. The survey used for this study was implemented during the COVID-19 lockdown situation. That is why the samples might include some level of bias. Since the lockdown period is over, researchers can easily reach randomly selected respondents and conduct face-to-face surveys with them. Thus, it is recommended that the researcher search the values and preferences concerning gardens for tenants after the pandemics.

Author Contributions: Conceptualization, A.B. and Z.F.R.A.; methodology, N.M.N.A.M., Z.F.R.A. and A.B.; investigation, N.M.N.A.M.; data curation, Z.F.R.A. and A.B.; writing-original draft preparation, N.M.N.A.M.; writing-review and editing, Z.F.R.A. and A.B; supervision, Z.F.R.A. and A.B.; funding acquisition, Z.F.R.A. All authors have read and agreed to the published version of the manuscript.

Funding: This research was funded by the United Arab Emirates University (UAEU), Horticulture Master Program.

Institutional Review Board Statement: Not applicable.

Informed Consent Statement: Not applicable.

Data Availability Statement: Not applicable.

Acknowledgments: The authors are grateful to United Arab Emirates University, Horticulture master program of the Integrative Agriculture Department, College of Agriculture and Veterinary Medicine for funding this project.

Conflicts of Interest: The authors declare no conflict of interest. The funders had no role in the design of the study; in the collection, analyses, or interpretation of data; in the writing of the manuscript, or in the decision to publish the results.

\section{References}

1. Dictionary, M.-W. Definition of Barrier; Merriam-Webster Inc.: Springfield, MO, USA, 2020.

2. Dennis, M.; James, P. Evaluating the relative influence on population health of domestic gardens and green space along a rural-urban gradient. Landsc. Urban Plan. 2017, 157, 343-351. [CrossRef]

3. Sofo, A.; Sofo, A. Converting Home Spaces into Food Gardens at the Time of Covid-19 Quarantine: All the Benefits of Plants in this Difficult and Unprecedented Period. Hum. Ecol. 2020, 48, 131-139. [CrossRef] [PubMed]

4. Brindley, P.; Jorgensen, A.; Maheswaran, R. Domestic gardens and self-reported health: A national population study. Int. J. Health Geogr. 2018, 17, 31. [CrossRef] [PubMed]

5. Campbell, B.L.; Rihn, A.L.; Campbell, J.H. Impact of the Coronavirus pandemic on plant purchasing in Southeastern United States. Agribusiness 2021, 37, 160-170. [CrossRef]

6. Pavao-Zuckerman, M.A. The nature of urban soils and their role in ecological restoration in cities. Restor. Ecol. 2008, 16, 642-649. [CrossRef]

7. $\quad$ Lee, K.E.; Williams, K.J.; Sargent, L.D.; Farrell, C.; Williams, N.S. Living roof preference is influenced by plant characteristics and diversity. Landsc. Urban Plan. 2014, 122, 152-159. [CrossRef]

8. Chaudhary, V.B.; Sandall, E.L.; Lazarski, M.V. Urban mycorrhizas: Predicting arbuscular mycorrhizal abundance in green roofs. Fungal Ecol. 2019, 40, 12-19. [CrossRef]

9. John, J.; Kernaghan, G.; Lundholm, J. The potential for mycorrhizae to improve green roof function. Urban Ecosyst. 2017, 20, 113-127. [CrossRef]

10. Twedt, E.; Rainey, R.M.; Proffitt, D.R. Designed natural spaces: Informal gardens are perceived to be more restorative than formal gardens. Front. Psychol. 2016, 7, 88. [CrossRef] [PubMed]

11. Waliczek, T.M.; Lineberger, R.D.; Zajicek, J.M.; Bradley, J.C. Using a Web-based Survey to Research the Benefits of Children Gardening. HortTechonlogy 2000, 10, 71-76. [CrossRef]

12. Dunnett, N.; Qasim, M. Perceived benefits to human well-being of urban gardens. HortTechnology 2000, 10, 40-45. [CrossRef]

13. Hartig, T.; Mitchell, R.; De Vries, S.; Frumkin, H. Nature and health. Annu. Rev. Public Health 2014, 35, 207-228. [CrossRef] [PubMed]

14. Jennings, V.; Gaither, C.J. Approaching environmental health disparities and green spaces: An ecosystem services perspective. Int. J. Environ. Res. Public Health 2015, 12, 1952-1968. [CrossRef] [PubMed] 
15. Bratman, G.N.; Hamilton, J.P.; Daily, G.C. The impacts of nature experience on human cognitive function and mental health. Ann. N. Y. Acad. Sci. 2012, 1249, 118-136. [CrossRef] [PubMed]

16. Russell, R.; Guerry, A.D.; Balvanera, P.; Gould, R.K.; Basurto, X.; Chan, K.M.; Klain, S.; Levine, J.; Tam, J. Humans and nature: How knowing and experiencing nature affect well-being. Annu. Rev. Environ. Resour. 2013, 38, 473-502. [CrossRef]

17. Pope, D.; Tisdall, R.; Middleton, J.; Verma, A.; Van Ameijden, E.; Birt, C.; Macherianakis, A.; Bruce, N. Quality of and access to green space in relation to psychological distress: Results from a population-based cross-sectional study as part of the EURO-URHIS 2 project. Eur. J. Public Health 2018, 28, 35-38. [CrossRef] [PubMed]

18. Coombes, E.; Jones, A.P.; Hillsdon, M. The relationship of physical activity and overweight to objectively measured green space accessibility and use. Soc. Sci. Med. 2010, 70, 816-822. [CrossRef]

19. Maas, J.; Van Dillen, S.M.; Verheij, R.A.; Groenewegen, P.P. Social contacts as a possible mechanism behind the relation between green space and health. Health Place 2009, 15, 586-595. [CrossRef] [PubMed]

20. Mytton, O.; Townsend, N.; Rutter, H.; Foster, C. Green space and physical activity: An observational study using Health Survey for England data. Health Place 2012, 18, 1034-1041. [CrossRef] [PubMed]

21. Corley, J.; Okely, J.A.; Taylor, A.M.; Page, D.; Welstead, M.; Skarabela, B.; Redmond, P.; Cox, S.R.; Russ, T.C. Home garden use during COVID-19: Associations with physical and mental wellbeing in older adults. J. Environ. Psychol. 2021, 73, 101545. [CrossRef]

22. Ahmadpoor, N.; Shahab, S. Realising the value of greenspace: A planners' perspective on the COVID-19 pandemic. Town Plan. Rev. 2021, 92, 49-56. [CrossRef]

23. Ferrini, F.; Gori, A. Cities after COVID-19: How trees and green infrastructures can help shaping a sustainable future. Ri-Vista 2020, 19, 182-191.

24. Cervinka, R.; Schwab, M.; Schönbauer, R.; Hämmerle, I.; Pirgie, L.; Sudkamp, J. My garden—My mate? Perceived restorativeness of private gardens and its predictors. Urban For. Urban Green. 2016, 16, 182-187. [CrossRef]

25. Chalmin-Pui, L.S.; Griffiths, A.; Roe, J.; Heaton, T.; Cameron, R. Why garden?-Attitudes and the perceived health benefits of home gardening. Cities 2021, 112, 103118. [CrossRef]

26. Fox, D. Leisure time preference: The influence of gardening on garden visitation. World Leis. J. 2017, 59, 45-53. [CrossRef]

27. Cheng, E.; Stebbins, R.; Packer, J. Serious leisure among older gardeners in Australia. Leis. Stud. 2017, 36, 505-518. [CrossRef]

28. Kirkpatrick, J.B.; Davison, A. Home-grown: Gardens, practices and motivations in urban domestic vegetable production. Landsc. Urban Plan. 2018, 170, 24-33. [CrossRef]

29. McFarland, A.; Waliczek, T.M.; Etheredge, C.; Sommerfeld Lillard, A.J. Understanding Motivations for Gardening Using a Qualitative General Inductive Approach. HortTechnology 2018, 28, 289-295. [CrossRef]

30. Neild, B. Day Trip from Abu Dhabi: The Cool Oasis of Al Ain; One CNN Center: Atlanta, GA, USA, 2018.

31. Gillett, K. Visit the Garden City: New Bus Route Launched between Dubai and Al Ain; The National News: Abu Dhabi, United Arab Emirates, 2019. Available online: https:/ / www.thenationalnews.com/lifestyle/travel/visit-the-garden-city-new-bus-routelaunched-between-dubai-and-al-ain-1.848718. (accessed on 2 January 2022).

32. Maddala, G.S. Limited-Dependent and Qualitative Variables in Econometrics; Cambridge University Press: Cambridge, UK, 1983.

33. Scott Long, J. Regression Models for Categorical and Limited Dependent Variables; Sage: Los Angeles, CA, USA, $1997 ;$ Volume 7.

34. Chenarides, L.; Grebitus, C.; Lusk, J.L.; Printezis, I. Who practices urban agriculture? An empirical analysis of participation before and during the COVID-19 pandemic. Agribusiness 2021, 37, 142-159. [CrossRef]

35. Walljasper, C.; Polansek, T. Home Gardening Blooms around the World during Coronavirus Lockdowns. Reuters. 2020. Available online: https:/ / www.reuters.com/article/us-health-coronavirus-gardens/home-gardeningblooms-around-the-world-duringcoronavirus-lockdowns-idUSKBN2220D3 (accessed on 2 January 2022).

36. de Bell, S.; White, M.; Griffiths, A.; Darlow, A.; Taylor, T.; Wheeler, B.; Lovell, R. Spending time in the garden is positively associated with health and wellbeing: Results from a national survey in England. Landsc. Urban Plan. 2020, 200, 103836. [CrossRef] 